\title{
Behavior of Escherichia coli 0157:H7 during the manufacture and ripening of Fontina Protected Designation of Origin cheese
}

\author{
A. Bellio, ${ }^{* 1}$ D. M. Bianchi, ${ }^{*}$ N. Vitale, $†$ L. Vernetti, $\ddagger$ S. Gallina, ${ }^{*}$ and L. Decastelli* \\ *Struttura Complessa Controllo Alimenti e Igiene delle Produzioni, and \\ †Struttura Semplice Osservatorio Epidemiologico, Istituto Zooprofilattico Sperimentale del Piemonte, Liguria e Valle d'Aosta, via Bologna 148, \\ 10154 Turin, Italy \\ łlnstitut Agricole Régional, Regione la Rochere 1, 11100 Aoste, Italy
}

\begin{abstract}
This study was conducted to describe the cheesemaking procedure of Fontina Protected Designation of Origin (PDO) cheese and to evaluate the behavior of Escherichia coli O157:H7 during cheese manufacture and ripening. The study was divided into 2 phases: the production of Fontina PDO cheese was monitored at 3 different dairies in the Aosta Valley and an E. coli O157 challenge was conducted at a fourth dairy. The dairies employ different commercial starter cultures for cheese making. The growth of lactic acid bacilli (LAB) and the decrease in $\mathrm{pH}$ were slower in the first hours and the LAB concentrations were overall higher in dairy A than in the other 2 dairies. The $\mathrm{pH}$ remained substantially unchanged during ripening (range 5.2 to 5.4) in all dairies. Water activity remained constant at around 0.98 until d 21, when it decreased to around 0.97 until d 80 in dairies A and B and 0.95 in dairy E. Whole raw cow milk was used for making Fontina cheese according to the standard procedure. For the experimental production, the milk was inoculated with E. coli O157:H7 at a concentration of approximately $5 \log _{10} \mathrm{cfu} / \mathrm{mL}$ and commercial starter cultures were used according to the Fontina PDO regulation. An increase of $2.0 \log _{10} \mathrm{cfu} / \mathrm{g}$ in E. coli O157:H7 was observed during the first $9.5 \mathrm{~h}$ of cheese making, followed by a decrease at $46 \mathrm{~h}$ when $\mathrm{pH}$ decreased to 5.4 in all trials. Fresh cheeses were salted and held at $10^{\circ} \mathrm{C}$ for ripening for $80 \mathrm{~d}$. Water activity was decreased to 0.952 at the end of the ripening stage. The LAB concentrations declined gradually; this trend was more marked for the lactobacilli than either the thermophilic or the mesophilic lactococci. The increase in LAB count and the decrease in $\mathrm{pH}$ in the first hours did not seem to affect $E$. coli $\mathrm{O} 157$ growth. Ripening was found to inhibit pathogen survival, however, as seen in the reduction of $3 \log _{10}$ from the maximum
\end{abstract}

Received July 7, 2017.

Accepted February 18, 2018.

${ }^{1}$ Corresponding author: alberto.bellio@izsto.it concentration measured during the earlier stages of production.

Key words: Escherichia coli O157, Fontina Protected Designation of Origin, cheese, cheese making, ripening

\section{INTRODUCTION}

Domestic animals for milk production are a known major reservoir of verotoxin-producing Escherichia coli (VTEC) and are often asymptomatic carriers (Caprioli et al., 2005). Contaminated raw milk and dairy products prepared from contaminated raw milk are a potential source of outbreaks caused by Escherichia coli O157:H7 (Honish et al., 2005; Baylis, 2009; Ravel et al., 2009), as also previously reported for Italy (Trevisani et al., 2014; Nobili et al., 2016). The VTEC can cause human infections ranging from uncomplicated diarrhea to such severe diseases as life-threatening hemolytic uremic syndrome and hemorrhagic colitis (Melton-Celsa et al., 2011). In susceptible individuals, the infective dose of VTEC is less than 10 bacteria; to ensure food safety, no VTEC must be present in the cheese (Callon et al., 2016). Behavior of VTEC depends on the temperatures during cheese manufacture and ripening according to the cheese-making method (Farrokh et al., 2013). For these reasons, researchers have examined the behavior of E. coli O157:H7 during the manufacture and aging of various cheese varieties such as feta, telemes, Grana Padano Protected Designation of Origin (PDO), Cheddar, Camembert, and Gouda cheese (Govaris et al., 2002; Ercolini et al., 2005; Schlesser et al., 2006; Montet et al., 2009; D'Amico et al., 2010). Furthermore, because many regional cheese specialties are made from unpasteurized milk, they may pose a threat to consumer safety by transmitting pathogens such as E. coli O157:H7 (Vernozy-Rozand et al., 2005). Contamination by VTEC is also an important microbiological cause of dairy product recalls in Europe (RASFF, 2017). In 2014, the European Food Safety Authority and the European Centre for Disease Prevention and Control reported that $3.6 \%$ of raw cow 
milk samples and $1.2 \%$ of milk (excluding raw cow milk) and dairy products tested positive for VTEC, with an increase in the proportion of VTEC-positive samples in the European Union over previous years (EFSA and ECDC, 2016).

No studies to date have investigated the behavior of E. coli O157 during the production of Fontina. Fontina is a PDO cheese with a semi-cooked paste made from whole raw cow milk collected from a single milking. Produced in the Aosta Valley in northwest Italy, it is obtained from cow milk from the indigenous valdostana (pezzatarossa, pezzatanera, and castana) breed, which has long been reared for milk production. The milk's characteristics derive from feeding with fodder essences typical of the alpine area; the cheese's characteristics reflect the qualities of raw milk. The cheese must be ripened for at least $80 \mathrm{~d}$ according to the Fontina PDO regulation.

Raw milk cheese production and commercialization is regulated in Europe under regulation no. 853/2004 (European Union, 2004) which lays down specific hygiene rules for food of animal origin including raw milk cheese. Generally, unsafe food shall not be placed on the European market (European Union, 2002) and microbiological criteria are defined for different kinds of food matrices. Moreover, national laws describe safety criteria related to specific food products: in Italy, VTEC are well regulated in cheese and must be absent in $25 \mathrm{~g}$ (Regione Piemonte, 2017).

Fontina was exported to European Union Member States (428 t), the United States (346 t), and Asia (18 t) in 2016 (CLAL, 2017). Some countries pose restrictions on the importation of cheeses made from unpasteurized milk. Food safety regulation requires the demonstration that the level of pathogenic microorganisms in the raw milk cheese does not exceed the level of these microorganisms in the milk from which the cheese was made. Also, it is mandatory that the raw milk cheese does not support the growth of pathogenic microorganisms (Ryser, 2011; Food Standards Australia New Zealand, 2015).

The objectives of this study were to describe Fontina PDO production and to determine the survival of $E$. coli O157:H7 during cheese manufacture and ripening.

\section{MATERIALS AND METHODS}

\section{Study Design}

The study was divided into a pilot and an experimental phase. The aim of pilot phase was to analyze the entire Fontina PDO production process at 3 dairies. A fourth dairy was selected for the experimental phase in which the microbial challenge with E. coli $\mathrm{O} 157: \mathrm{H} 7$ was performed. For the pilot phase, 3 dairies were selected from among the 20 major Fontina PDO producers in the Aosta Valley.

Temperature was monitored with a data logger (FT800, Maxim Integrated Products, San Jose, CA) during the production process. Three production batches were monitored at each dairy. Milk, curd, and cheese were sampled to enumerate lactic acid bacilli $(\mathbf{L A B})$ and measure $\mathrm{pH}$ and water activity $\left(\mathbf{A}_{\mathrm{w}}\right)$ at $0,2,2.5,12$, and $24 \mathrm{~h}$ and at 7, 14, 21, 56, and $80 \mathrm{~d}$. Milk (100 mL) and curd (100 g) samples were collected with a sterile $25-\mathrm{mL}$ serological pipette and a silver spoon, respectively. Each cheese sample $(30 \mathrm{~g})$ was obtained from 3 different wheel sites (10 g each) with a sterile silver corer and then pooled.

The aim of the experimental phase was to study the behavior of $E$. coli $\mathrm{O} 157: \mathrm{H} 7$ during cheese production in a fourth dairy. Three batches of Fontina PDO were made from milk spiked with 3 different E. coli O157 strains. For the experimental phase, on the selected dairy characteristics, following a repeated ANOVA design, 3 batches of contaminated E. coli O157:H7 samples were collected during the entire production process. The batches were uncontaminated and contaminated milk, curd and whey after cutting, whey and curd after cooking, and curd before pressing, after $6 \mathrm{~h}$ of pressing, and before and after salting and ripening $(7,14,21,28$, 56 , and $80 \mathrm{~d}$ ). The following parameters were measured: LAB, $\mathrm{pH}, \mathrm{A}_{\mathrm{w}}$, and E. coli $\mathrm{O} 157$ concentration.

\section{Microbiological Analysis}

From each sample collected as described above, $10 \pm$ $0.5 \mathrm{~g}$ was homogenized with $90 \mathrm{~mL}$ of buffered peptone water (Oxoid, Milan, Italy) for $2 \mathrm{~min}$ in a stomacher (LAB Blender 400, PBI, Milan, Italy). Decimal dilutions in sterile peptone water (Oxoid) were prepared, and aliquots of the dilutions were spread on a specific medium according to ISO (2017). Thermophilic and mesophilic lactococci were enumerated with M17 medium (Oxoid) at $45^{\circ} \mathrm{C}$ for $48 \mathrm{~h}$ and at $30^{\circ} \mathrm{C}$ for $72 \mathrm{~h}$, respectively. Thermophilic streptococci count was performed using de Man, Rogosa, and Sharpe agar (MRS, Oxoid) incubated at $45^{\circ} \mathrm{C}$ for $48 \mathrm{~h}$ (Bellio et al., 2016).

The $\mathrm{pH}$ was measured by immersing the probe of the pH meter (GLP 22, Crison, Barcelona, Spain) in milk/ whey or in a diluted and homogenized sample containing $10 \mathrm{~g}$ of curd/cheese sample and $10 \mathrm{~mL}$ of distilled water (MFHPB, 2014). Water activity was measured with a calibrated electric hygrometer (Aqualab, Decagon Devices Inc., Pullman, WA) according to ISO (2004). 


\section{Inoculum Preparation}

Three different E. coli $\mathrm{O} 157$ strains were used: E. coli O157 (NCTC 12900), E. coli O157 (strain EF 390), and E. coli $\mathrm{O} 157$ (strain EF 430) kindly provided by the European Union Reference Laboratory for Escherichia coli, including VTEC. The 2 wild strains were isolated from raw cow milk and carried virulence genes eae but not stx1 or stx2. All strains were kept in cryobeads (AEB 400100, AES Laboratories, Combourg, France) and maintained at $-20^{\circ} \mathrm{C}$. Each strain was grown twice in $10 \mathrm{~mL}$ of brain heart infusion broth (Oxoid, Basingstoke, Hampshire, UK) at $37^{\circ} \mathrm{C}$ for $24 \mathrm{~h}$ to revive the culture ( $1 \%$ inoculum) and then incubated at $37^{\circ} \mathrm{C}$ for $24 \mathrm{~h}$ separately. Cultures of each strain were then pooled to obtain a bacterial suspension with a final concentration of about $9 \log _{10} \mathrm{cfu} / \mathrm{mL}$.

\section{Experimental Production}

Experimental production of Fontina PDO was carried out according to the cheese-making process used at dairy A, which was designated as the worst-case scenario based on slower LAB growth and decreased $\mathrm{pH}$ (Table 1). Each batch was prepared from $90 \mathrm{~L}$ of raw milk. According to the regulations for Fontina PDO production, raw milk must be used within $2 \mathrm{~h}$ after milking without refrigeration. The milk was delivered at $35^{\circ} \mathrm{C}$ to the experimental dairy (dairy S) and emptied into a stainless-steel container. The batches were artificially contaminated with an inoculum of E. coli O157. Bacterial suspension $(10 \mathrm{~mL})$ at $37^{\circ} \mathrm{C}$ was mixed gently and gradually distributed into the raw milk under stirring to achieve uniform distribution of the inoculum and a final concentration of approximately 5 to $6 \log _{10}$ $\mathrm{cfu} / \mathrm{mL}$. A freeze-dried starter culture $(1.5 \mathrm{~g} / 100 \mathrm{~L})$ containing a LAB mixture of Streptococcus thermophilus, Lactococcus lactis, and Lactobacillus delbrueckii ssp. Lactis [FT-1 D, Bioagro, Thiene (VI), Italy] was prepared according to regulations for Fontina PDO production (Repubblica Italiana, 2011) and added to obtain approximately 5 to $6 \log _{10} \mathrm{cfu} / \mathrm{mL}$. The milk was stirred, warmed to $37^{\circ} \mathrm{C}$, and $1 \mathrm{mg} / 100 \mathrm{~L}$ of powdered calf rennet [Caglificio Clerici, Cadorago (CO), Italy] was added. After curdling, the curd was cut into pieces $0.5 \mathrm{~cm}$ in diameter and heated to $48^{\circ} \mathrm{C}$ in $1 \mathrm{~h}$. The curd was transferred to molds $(50 \mathrm{~cm}$ in diameter and $7 \mathrm{~cm}$ thick) and mechanically pressed at 300 to $400 \mathrm{kPa}$ for $20 \mathrm{~h}$ to drain. The cheese was salted by immersion in $22 \%$ (wt/vol) brine in a climate-controlled room for 12 h (temperature $10^{\circ} \mathrm{C}$, relative humidity $90 \%$ ). For each batch, brine was produced with boiling water and salt and then maintained in a climate-controlled room at $10^{\circ} \mathrm{C}$. The cheese wheel was transferred to a wooden board in a climate-controlled room for ripening for $80 \mathrm{~d}$ at $10^{\circ} \mathrm{C}$ and relative humidity of $90 \%$.

For each trial, in conformity with ISO/TS 13136:2012, we checked that $E$. coli $\mathrm{O} 157: \mathrm{H} 7$ was not initially present in the raw milk. Inoculation levels were measured by sampling the inoculated milk. Analyses were performed as described above (LAB, $\mathrm{pH}$, and $\left.\mathrm{A}_{\mathrm{w}}\right)$. Escherichia coli O157 was enumerated on CHROMagar O157 (CHROMagar, Springfield, NJ) incubated for $24 \mathrm{~h}$ at $37^{\circ} \mathrm{C}$.

\section{Statistical Data Analysis}

Data were analyzed using SAS software (version 9.2, SAS Institute, Cary, NC). Microbiological counts were converted to $\log _{10}$ colony-forming units. For each parameter (LAB, $\mathrm{pH}, \mathrm{A}_{\mathrm{w}}$, E. coli O157, and temperature), descriptive statistics of the mean \pm standard deviation, median, minimum, and maximum values were calculated. To select the dairy for the experimental phase, the dairies were compared using nonparametric and parametric ANOVA. To compare the overall effect of LAB and $\mathrm{pH}$ between the 3 dairies, the Kruskal-Wallis $\mathrm{H}$ test was performed. The effect of time on microbiological flora, $\mathrm{A}_{\mathrm{w}}$, and $\mathrm{pH}$ at each dairy was investigated using 1-way ANOVA. The PROC GLM in SAS was used with time as factor. When ANOVA revealed significant differences $(P<0.05)$, the Tukey honestly significant difference test was applied. Differences in $E$. coli $\mathrm{O} 157: \mathrm{H} 7$ concentration between the 3 batches were evaluated by 1-way ANOVA.

To determine E. coli O157:H7 survival during production, the difference in E. coli O157 counts between whey and curd were compared using the Wilcoxon test. Dairy and time were entered as factors in 2-way ANOVA to compare $\mathrm{A}_{\mathrm{w}}, \mathrm{pH}$, and LAB between the 3 dairies (A, B, and E) and the fourth dairy (S) selected for the experimental study. Dairy was entered into the analysis to compare all 4 dairies. Because production times differed between the dairies, 3 time points were used: the beginning (starting time), at $12 \mathrm{~h}$, and at the end of ripening $(80 \mathrm{~d})$. Of note, $\mathrm{A}_{\mathrm{w}}$ was compared only at 2 time points: $12 \mathrm{~h}$ and the end of ripening. Interaction between the factors dairy and time was also compared. When ANOVA showed significant effects, post hoc analysis was done using Tukey's honestly significant difference test $(P \leq 0.05)$.

\section{RESULTS AND DISCUSSION}

\section{Production Process}

The production process at the 3 dairies differed in several ways. The commercial starter culture used at dairy A contained LAB S. thermophilus, Lc. lactis, and 
Lb. delbrueckii ssp. lactis (FT-1 D, Bioagro), whereas at the other 2 dairies it contained $S$. thermophilus, $L c$. lactis, and Lb. rhamnosus (FT-N D, Bioagro). None of these strains has been reported to produce bacteriocins against $E$. coli $\mathrm{O} 157$. In dairies $\mathrm{B}$ and $\mathrm{E}, 2$ batches per day are produced from morning and evening milk collections, respectively. During the pressing stage $(12 \mathrm{~h})$, the cheese wheels are overturned to facilitate draining of the cheese mass. The wheel is then placed in brine for $12 \mathrm{~h}$. In dairy A, Fontina PDO is made only from the morning milk collection, while the evening yield is used for other dairy products. In addition, the cheese wheels are pressed for $20 \mathrm{~h}$ and then transferred to brine for $12 \mathrm{~h}$.

No statistically significant difference in LAB concentration added to the starter milk was found between the 3 dairies $(\mathrm{H}$ test $=3.3449$, $\mathrm{df}=2, P=0.1878)$ : mesophilic and thermophilic lactococci ranged from 5.5 to $6.0 \log _{10} \mathrm{cfu} / \mathrm{mL}$ and lactobacilli from 4.5 to $5.0 \log _{10}$ $\mathrm{cfu} / \mathrm{mL}$. At dairies B and $\mathrm{E}$, the LAB concentrations gradually increased during the early stages of process- ing and reached about 6.5, 7.5, and $7.0 \log _{10} \mathrm{cfu} / \mathrm{g}$ for lactobacilli, thermophilic, and mesophilic lactococci, respectively, after $12 \mathrm{~h}$ (Table 1 ).

In dairy $\mathrm{A}$, the effect of time was statistically significant for $\mathrm{A}_{\mathrm{w}}(\mathrm{F}=14.1, P<0.0001)$, mesophilic lactococci $(\mathrm{F}=42.5, P<0.0001)$, thermophilic lactococci $(\mathrm{F}=109.9, P<0.0001)$, lactobacilli $(\mathrm{F}=58.3, P<$ $0.0001)$, and $\mathrm{pH}(\mathrm{F}=587.8, P<0.0001)$. In dairy $\mathrm{B}$, the effect of time was statistically significant for $A_{w}$ ( $F$ $=45.9, P<0.0001)$, mesophilic lactococci $(\mathrm{F}=15.3$, $P<0.0001)$, thermophilic lactococci $(\mathrm{F}=21.7, P<$ $0.0001)$, lactobacilli $(\mathrm{F}=23.6, P<0.0001)$, and $\mathrm{pH}(\mathrm{F}$ $=73.4, P<0.0001)$. In dairy $\mathrm{E}$, the effect of time was statistically significant for $\mathrm{A}_{\mathrm{w}}(\mathrm{F}=48.8, P<0.0001)$, mesophilic lactococci ( F 13.7, $P<0.0001$ ), thermophilic lactococci $(\mathrm{F}=12.9, P<0.0001)$, lactobacilli (F $=17.7, P<0.0001)$, and $\mathrm{pH}(\mathrm{F}=247.3, P<0.0001)$.

In dairy A, slower LAB growth was noted in the first hours but ultimately reached higher concentrations than those observed for the 2 other dairies. This difference was related to the more rapid decrease in $\mathrm{pH}(5.4$

Table 1. Changes in $\mathrm{pH}$, water activity $\left(\mathrm{A}_{\mathrm{w}}\right)$, thermophilic, and mesophilic lactococci, and lactobacilli counts in Fontina Protected Designation of Origin cheese samples from the 3 pilot study dairies $(A, B \text {, and } E)^{1}$

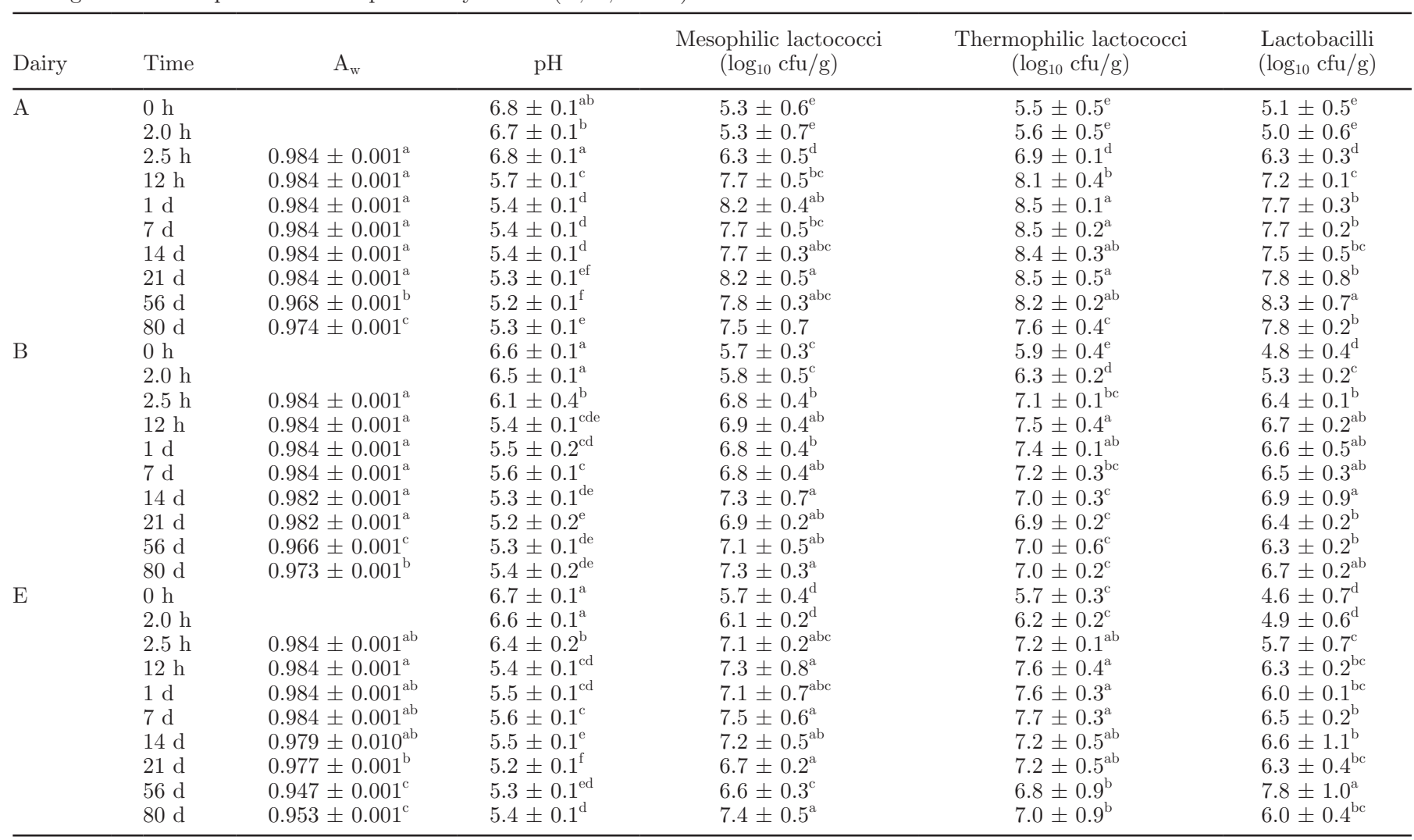

${ }^{\mathrm{a} f}$ Within a column, mean values with the same superscript letter are not statistically different $(P>0.05)$.

${ }^{1}$ Values are means \pm SD. Time was statistically significant within each dairy for each parameter. Post hoc comparison using Tukey's honestly significant difference test is reported. 
Table 2. Changes in temperature $\left({ }^{\circ} \mathrm{C}\right)$ in Fontina Protected Designation of Origin cheese samples from 3 pilot study dairies (A, B, and E) and from the experimental study dairy $(\mathrm{S})^{1}$

\begin{tabular}{lrrrr}
\hline Time & Dairy A & Dairy B & Dairy E & Dairy S \\
\hline 0 & $25.2 \pm 0.8$ & $30.0 \pm 2.2$ & $30.3 \pm 1.5$ & $25.1 \pm 0.6$ \\
$1.0 \mathrm{~h}$ & $36.8 \pm 0.3$ & $36.3 \pm 0.3$ & $36.2 \pm 0.3$ & $36.0 \pm 1.0$ \\
$2.0 \mathrm{~h}$ & $47.5 \pm 1.2$ & $47.4 \pm 0.4$ & $47.8 \pm 0.3$ & $47.9 \pm 0.7$ \\
$2.5 \mathrm{~h}$ & $46.4 \pm 0.6$ & $46.0 \pm 0.5$ & $45.8 \pm 0.4$ & $44.0 \pm 0.8$ \\
$8.5 \mathrm{~h}$ & $39.7 \pm 0.8$ & $41.5 \pm 3.5$ & $39.5 \pm 3.5$ & $32.0 \pm 0.8$ \\
$1 \mathrm{~d}$ & $12.5 \pm 0.3$ & $15.5 \pm 0.2$ & $12.8 \pm 0.4$ & $13.7 \pm 0.3$ \\
$7 \mathrm{~d}$ & $9.4 \pm 0.1$ & $9.3 \pm 0.3$ & $8.8 \pm 0.3$ & $9.5 \pm 0.3$ \\
$14 \mathrm{~d}$ & $9.4 \pm 0.1$ & $9.3 \pm 0.3$ & $8.8 \pm 0.3$ & $9.5 \pm 0.3$ \\
$21 \mathrm{~d}$ & $9.4 \pm 0.1$ & $9.3 \pm 0.3$ & $8.8 \pm 0.3$ & $9.5 \pm 0.3$ \\
$56 \mathrm{~d}$ & $9.4 \pm 0.1$ & $9.3 \pm 0.3$ & $8.8 \pm 0.3$ & $9.5 \pm 0.3$ \\
$80 \mathrm{~d}$ & $9.4 \pm 0.1$ & $9.3 \pm 0.3$ & $8.8 \pm 0.3$ & $9.5 \pm 0.3$ \\
\hline
\end{tabular}

${ }^{1}$ Values are means $\pm \mathrm{SD}$.

\pm 0.1 ) in dairies $\mathrm{B}$ and $\mathrm{E}$ (at $12 \mathrm{~h}$ ) as compared with dairy A (at $24 \mathrm{~h})$. The $\mathrm{pH}$ level was higher in dairy A than that measured in either dairy $\mathrm{B}$ or $\mathrm{E}$ at $2.5 \mathrm{~h}$ and the difference was statistically significant $(\mathrm{H}$ test 15.1 ; $P<0.001$ ). The $\mathrm{pH}$ remained substantially unchanged during the ripening period, with a slight decrease at $21 \mathrm{~d}(5.1 \pm 0.1)$ in dairy E. The LAB concentrations during the ripening period were constantly high, resulting in a product with a high amount of live LAB. The LAB concentrations were higher in dairy A than in the 2 other dairies; the difference was statistically significant ( $\mathrm{H}$ test $16.9 ; P<0.001$ ). This difference could be attributed to the different starter cultures and particularly to pressing the cheese at room temperature for $24 \mathrm{~h}$ instead of $12 \mathrm{~h}$ (Table 2), which allowed for greater growth of lactobacilli $\left(7.7 \pm 0.3 \log _{10} \mathrm{cfu} / \mathrm{g}\right)$, thermophilic $\left(8.5 \pm 0.1 \log _{10} \mathrm{cfu} / \mathrm{g}\right)$, and mesophilic lactococci $\left(8.2 \pm 0.4 \log _{10} \mathrm{cfu} / \mathrm{g}\right)$ at $24 \mathrm{~h}$. The $\mathrm{A}_{\mathrm{w}}$ remained constant at around 0.98 until d 21, when it decreased to around 0.97 until d 80 in dairies $\mathrm{A}$ and $\mathrm{B}$ and 0.95 in dairy $\mathrm{E}$.

\section{Experimental Production}

Analysis of variance comparison between the 4 dairies (A, B, E, and S) at 3 time points was statistically significant for $\mathrm{A}_{\mathrm{w}}$ for the 3 factors dairy $(\mathrm{F}=17.7, P<$ $0.0001)$, time $(\mathrm{F}=117.9, P<0.0001)$, and interaction $(\mathrm{F} 12.2, P<0.001)$. The same pattern was observed for $\mathrm{pH}$, dairy $(\mathrm{F}=4.8, P<0.01)$, time $(\mathrm{F}=789.6, P<$ $0.0001)$, interaction $(\mathrm{F}=3.9, P<0.05)$, and lactobacilli. As for lactobacilli, the 3 factors dairy $(\mathrm{F}=14.3, P$ $<0.0001)$, time $(\mathrm{F}=106.5, P<0.0001)$, and interaction $(\mathrm{F}=3.8, P<0.01)$ were statistically significant. However, post hoc analysis showed that dairy $\mathrm{S}$ did not differ statistically from dairy $\mathrm{E}$ for $\mathrm{A}_{\mathrm{w}}$ or from dairies $\mathrm{A}$ and $\mathrm{B}$ for $\mathrm{pH}$ and lactobacilli (Tables 3 and 4). The interaction between the factors time and dairy was not statistically significant for thermophilic and mesophilic lactococci $(\mathrm{F}=0.98, P=0.45$ and $\mathrm{F}=0.96, P=0.47$, respectively).

No studies to date have investigated the behavior of E. coli O157 during the making of Fontina PDO.

Table 3. Changes in $\mathrm{pH}$ and water activity $\left(\mathrm{A}_{\mathrm{w}}\right)$ in Fontina-type cheese samples during experimental production $^{1}$

\begin{tabular}{llcc}
\hline Cheese-making stage & Time & $\mathrm{A}_{\mathrm{w}}$ & $\mathrm{pH}$ \\
\hline Contaminated milk & 0 & & $6.8 \pm 0.1$ \\
Curd after cutting & $1.0 \mathrm{~h}$ & & $6.6 \pm 0.1$ \\
Curd after cooking & $2.0 \mathrm{~h}$ & & $6.5 \pm 0.1$ \\
Curd before pressing & $2.5 \mathrm{~h}$ & & $6.5 \pm 0.1$ \\
6 h of pressing & $8.5 \mathrm{~h}$ & & $6.0 \pm 0.3$ \\
Before salting & $12 \mathrm{~h}$ & $0.984 \pm 0.003$ & $5.7 \pm 0.1$ \\
Beginning of ripening & $1 \mathrm{~d}$ & $0.979 \pm 0.004$ & $5.4 \pm 0.1$ \\
7 d after ripening & $7 \mathrm{~d}$ & $0.973 \pm 0.004$ & $5.4 \pm 0.1$ \\
14 d after ripening & $14 \mathrm{~d}$ & $0.971 \pm 0.005$ & $5.3 \pm 0.1$ \\
21 d after ripening & $21 \mathrm{~d}$ & $0.965 \pm 0.006$ & $5.2 \pm 0.2$ \\
28 d after ripening & $28 \mathrm{~d}$ & $0.950 \pm 0.006$ & $5.2 \pm 0.2$ \\
56 d after ripening & $56 \mathrm{~d}$ & $0.952 \pm 0.006$ & $5.3 \pm 0.1$ \\
80 d after ripening & $80 \mathrm{~d}$ & & \\
\hline
\end{tabular}

${ }^{1}$ Values are means \pm SD. 


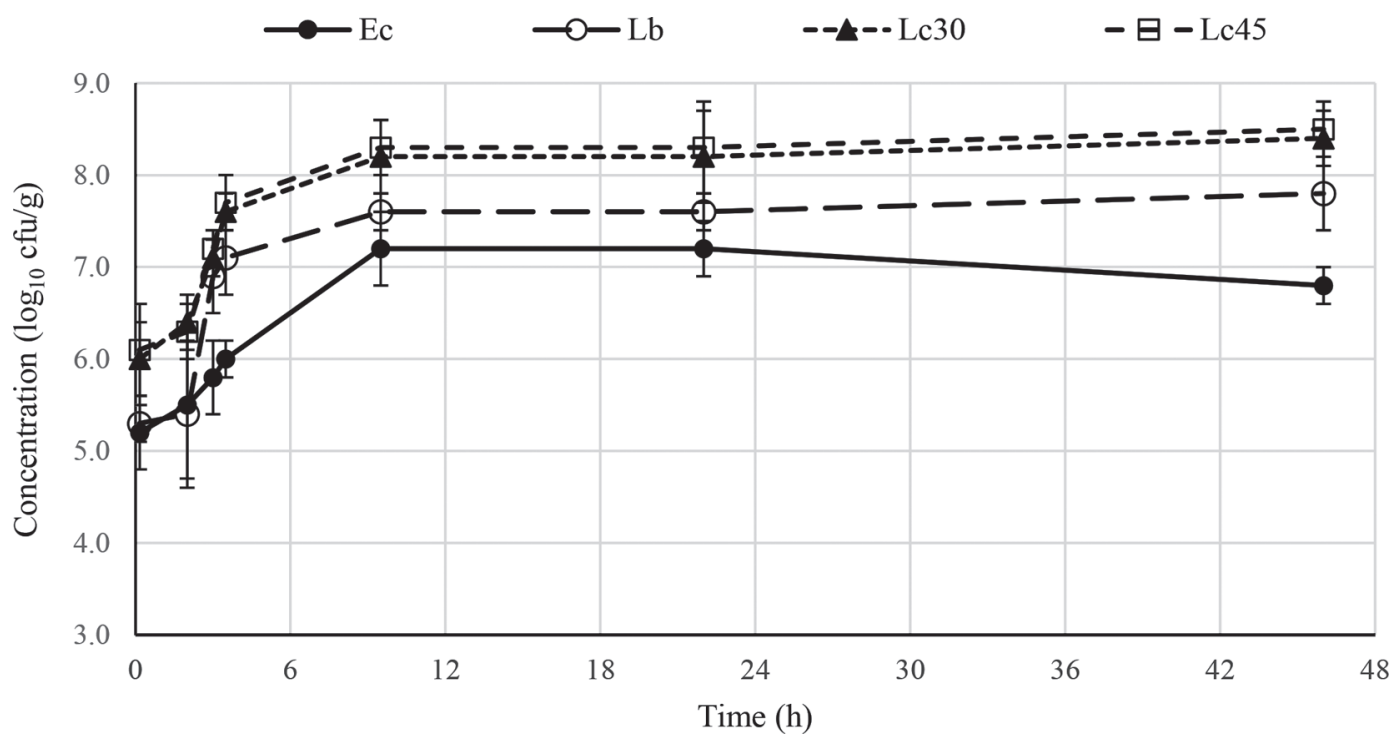

Figure 1. Changes in microbial count during Fontina-type cheese making in experimental productions. Ec $=$ Escherichia coli $\mathrm{O} 157$; Lb $=$ lactobacilli; Lc30 = mesophilic lacotococci; Lc45 = thermophilic lactococci. Error bars represent SD.

Nonetheless, the present findings can be compared with those from similar studies performed on other types of cheeses. Our results are shared by previous studies which reported that although E. coli O157 is able to survive during cheese production, its concentration decreases during ripening (Vernozy-Rozand et al., 2005; Montet et al., 2009; D'Amico et al., 2010).

In the present study, raw milk was inoculated to obtain a concentration of about $5 \log _{10} \mathrm{cfu} / \mathrm{mL}$. No difference in $E$. coli $\mathrm{O} 157$ concentration between the 3 batches was observed $(\mathrm{F}=0.45, P=0.63)$.

The results show that the $E$. coli $\mathrm{O} 157$ concentration increased during the early stages of the cheese-making process (Figure 1). At the end of the pressing stage, the E. coli $\mathrm{O} 157$ count was increased by $2 \log _{10} \mathrm{cfu} / \mathrm{g}$. The increase in E. coli O157:H7 after expulsion of whey and contraction of the curd during heating and pressing may have been due to entrapment of bacterial cells in the curd and population growth after a lag phase during the heating step. Most of the cells are trapped in the curd and only some are released into the whey (D'Amico et al., 2010).

The difference in E. coli $\mathrm{O} 157$ concentration between whey and curd was statistically significant (Wilcoxon test $=462.5, \mathrm{Z}=4.08, P<0.001):$ E. coli concentration in whey was $4.7 \pm 0.6 \log _{10} \mathrm{cfu} / \mathrm{mL}$ and $4.5 \pm 0.4$ $\log _{10} \mathrm{cfu} / \mathrm{mL}$, after cutting and after cooking, respectively, and appeared lower than that measured in the

Table 4. Changes in $\mathrm{pH}$, water activity $\left(\mathrm{A}_{\mathrm{w}}\right)$, thermophilic and mesophilic lactococci, and lactobacilli count in Fontina Protected Designation of Origin and Fontina-type cheese samples from pilot study dairies (A, B, and E) and from the experimental study dairy $(\mathrm{S})^{1}$

\begin{tabular}{|c|c|c|c|c|c|}
\hline Item & Time & Dairy A & Dairy B & Dairy E & Dairy S \\
\hline$A_{w}$ & $80 \mathrm{~d}$ & $0.974 \pm 0.008^{\mathrm{a}}$ & $0.973 \pm 0.001^{\mathrm{a}}$ & $0.947 \pm 0.012^{\mathrm{b}}$ & $0.952 \pm 0.006^{\mathrm{b}}$ \\
\hline $\mathrm{pH}$ & $80 \mathrm{~d}$ & $5.3 \pm 0.1^{\mathrm{a}}$ & $5.4 \pm 0.2^{\mathrm{b}}$ & $5.4 \pm 0.1^{\mathrm{ab}}$ & $5.3 \pm 0.1^{\mathrm{a}}$ \\
\hline \multirow[t]{2}{*}{ Mesophilic lactococci $\left(\log _{10} \mathrm{cfu} / \mathrm{g}\right)$} & $0 \mathrm{~h}$ & $5.3 \pm 0.6^{\mathrm{a}}$ & $5.7 \pm 0.3^{\mathrm{a}}$ & $5.7 \pm 0.4^{\mathrm{a}}$ & $6.0 \pm 0.4^{\mathrm{a}}$ \\
\hline & $12 \mathrm{~h}$ & $7.7 \pm 0.5^{\mathrm{a}}$ & $6.9 \pm 0.4^{\mathrm{a}}$ & $7.3 \pm 0.8^{\mathrm{a}}$ & $8.2 \pm 0.5^{\mathrm{a}}$ \\
\hline \multirow{2}{*}{ Thermophilic lactococci $\left(\log _{10} \mathrm{cfu} / \mathrm{g}\right)$} & $12 \mathrm{~h}$ & $8.1 \pm 0.4^{\mathrm{a}}$ & $7.5 \pm 0.4^{\mathrm{a}}$ & $7.6 \pm 0.4^{\mathrm{a}}$ & $8.3 \pm 0.5^{\mathrm{a}}$ \\
\hline & $80 \mathrm{~d}$ & $7.6 \pm 0.4^{\mathrm{a}}$ & $7.0 \pm 0.2^{\mathrm{a}}$ & $7.0 \pm 0.9^{\mathrm{a}}$ & $8.1 \pm 0.2^{\mathrm{a}}$ \\
\hline \multirow{3}{*}{ Lactobacilli $\left(\log _{10} \mathrm{cfu} / \mathrm{g}\right)$} & $0 \mathrm{~h}$ & $5.1 \pm 0.5^{\mathrm{a}}$ & $4.8 \pm 0.4^{\mathrm{ab}}$ & $4.6 \pm 0.7^{\mathrm{b}}$ & $5.3 \pm 0.2^{\mathrm{a}}$ \\
\hline & $12 \mathrm{~h}$ & $7.2 \pm 0.1^{\mathrm{a}}$ & $6.7 \pm 0.2^{\mathrm{b}}$ & $6.3 \pm 0.2^{\mathrm{c}}$ & $7.6 \pm 0.2^{\mathrm{a}}$ \\
\hline & $80 \mathrm{~d}$ & $7.8 \pm 0.2^{\mathrm{a}}$ & $6.7 \pm 0.2^{\mathrm{b}}$ & $6.0 \pm 0.4^{\mathrm{c}}$ & $6.5 \pm 0.3^{\mathrm{b}}$ \\
\hline
\end{tabular}

\footnotetext{
${ }^{a-c}$ Within a column, mean values with the same superscript letter are not statistically different $(P>0.05)$.
}

${ }^{1}$ Values are means \pm SD. Post hoc comparison using Tukey's honestly significant difference test is reported. 
respective curd samples (after cutting: $5.5 \pm 0.8 \log _{10}$ cfu/g, after cooking: $\left.5.8 \pm 0.4 \log _{10} \mathrm{cfu} / \mathrm{g}\right)$.

In the present study, the production temperature favored pathogen growth, which reached $7.2 \log _{10} \mathrm{cfu} / \mathrm{g}$ in the cheese at the end of the pressing stage. Heating stress during curd cooking did not affect $E$. coli O157 viability. In contrast, E. coli O157:H7 grew by approximately $2 \log _{10}$ in fresh cottage cheese but was completely inactivated during the heating phase $\left(57^{\circ} \mathrm{C}\right.$ for $1.5 \mathrm{~h}$; Arocha et al., 1992). High temperatures are unable to inactivate E. coli $\mathrm{O} 157: \mathrm{H} 7$ in Grana Padano $\mathrm{PDO}$ (up to $55^{\circ} \mathrm{C}$ ) and Indian paneer $\left(62^{\circ} \mathrm{C}\right.$ for $5 \mathrm{~min}$; Ercolini et al., 2005; Wahi et al., 2006).

Pressing overnight at room temperature appeared to have an effect on E. coli $\mathrm{O} 157$ counts in our samples. The population in curd was $6.0 \pm 0.2 \log _{10} \mathrm{cfu} / \mathrm{g}$ before and $7.2 \pm 0.3 \log _{10} \mathrm{cfu} / \mathrm{g}$ after pressing. Similarly, Reitsma and Henning (1996) reported increases in $E$. coli $\mathrm{O} 157: \mathrm{H} 7$ populations after pressing (overnight at $2.5 \mathrm{~kg} / \mathrm{cm}^{2}$ ) in Cheddar made from high inoculation milk $\left(3 \log _{10} \mathrm{cfu} / \mathrm{mL}\right)$ and decreases when the cheeses were inoculated with a lower concentration $\left(1 \log _{10}\right.$ $\mathrm{cfu} / \mathrm{mL})$.

We observed a slight reduction from $7.2 \pm 0.3$ to 6.8 $\pm 0.3 \log _{10} \mathrm{cfu} / \mathrm{g}$ after brining, which may be attributed to the increased susceptibility of E. coli O157:H7 to the antimicrobial effects of salt (Spano et al., 2003). At the end of the production process, the E. coli O157:H7 concentration was $4.0 \pm 0.3 \log _{10} \mathrm{cfu} / \mathrm{g}$ (Figure 2) as compared with an inoculum of approximately $5.0 \log _{10}$ $\mathrm{cfu} / \mathrm{mL}$. Its concentration deceased by about $3 \log _{10}$ $\mathrm{cfu} / \mathrm{g}$ during the ripening period from the maximum concentration of $7.2 \pm 0.3 \log _{10} \mathrm{cfu} / \mathrm{g}$. In their study on Cheddar cheese, Reitsma and Henning (1996) reported that E. coli O157:H7 grew and survived during the ripening stage. When the milk was initially inoculated with $3 \log _{10} \mathrm{cfu} / \mathrm{mL}$, viable bacteria were still present in the cheese after $158 \mathrm{~d}$. A significant increase in $E$. coli O157:H7 count was reported during the manufacture of Camembert cheese (Ramsaran et al., 1998). Unlike both Camembert and Cheddar, cottage cheese undergoes extensive heat treatment $\left(57^{\circ} \mathrm{C}\right.$ over a 1.5 -h period) during curd cooking (Vernozy-Rozand et al., 2005). Govaris et al. (2002) observed that E. coli O157:H7 inoculated in pasteurized milk for making Telemes cheese decreased during ripening and that viable bacteria were no longer present after 40 d. Viable $E$. coli $\mathrm{O} 157: \mathrm{H} 7$ cells were detected for up to $158 \mathrm{~d}$ (using an enrichment procedure) in Cheddar cheese made from milk inoculated at $3 \log _{10}$ cfu/mL (Reitsma and Henning, 1996). After an initial raw milk low inoculation $(1 \mathrm{cfu} / \mathrm{mL}), E$. coli $\mathrm{O} 157: \mathrm{H} 7$ was detected in Cheddar cheese at $180 \mathrm{~d}$ (D'Amico et al., 2010) and at $240 \mathrm{~d}$ (Schlesser et al., 2006) of aging. Schlesser et al. (2006) reported that viable E. coli O157:H7 cells were detected after more than 1 yr of aging in cheese made from milk with high inoculation levels (3 to $5 \log _{10} \mathrm{cfu} / \mathrm{mL}$ ).

In our study, the LAB concentration increased during the first hours of processing and reached maximum values already at $6 \mathrm{~h}$ when the cheese wheel was in the press (lactobacilli, $7.6 \pm 0.2 \log _{10} \mathrm{cfu} / \mathrm{g}$; thermophilic lactococci, $8.3 \pm 0.3 \log _{10} \mathrm{cfu} / \mathrm{g}$; and mesophilic lactococci, $8.2 \pm 0.2 \log _{10} \mathrm{cfu} / \mathrm{g}$; Figure 1). During the ripening stage, the concentrations declined gradually: this trend was more marked for the lactobacilli $(6.5 \pm$ $\left.0.2 \log _{10} \mathrm{cfu} / \mathrm{g}\right)$ than either the thermophilic $(8.1 \pm 0.2$ $\left.\log _{10} \mathrm{cfu} / \mathrm{g}\right)$ or the mesophilic lactococci $\left(8.0 \pm 0.2 \log _{10}\right.$ $\mathrm{cfu} / \mathrm{g})$.

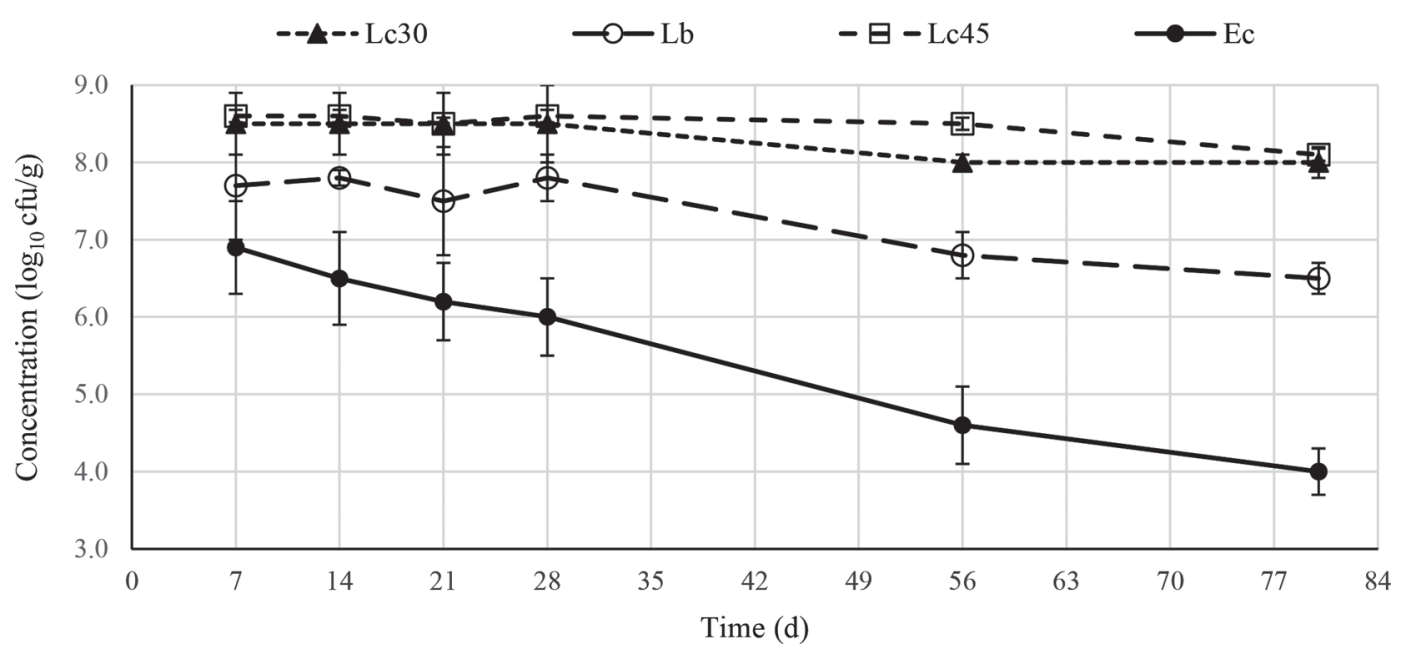

Figure 2. Changes in microbial count during Fontina-type cheese ripening in experimental production. Lc30 = mesophilic lacotococci; Lb $=$ lactobacilli; Lc45 = thermophilic lactococci; Ec = Escherichia coli O157. Error bars represent SD. 
Water activity decreased gradually during the ripening stage and reached 0.95 at d 80 (Table 3 ). The $\mathrm{pH}$ decreased rapidly during the first $24 \mathrm{~h}$ (average $\mathrm{pH} 5.3$ \pm 0.1 , after which it remained constant during ripening up to $\mathrm{d} 80$.

In conclusion, E. coli $\mathrm{O} 157$ can grow during the early stages of processing of Fontina PDO. Curd cooking $\left(48^{\circ} \mathrm{C}\right.$ for $\left.20 \mathrm{~min}\right)$ and preceding progressive heating to reach this temperature are insufficient to inactivate E. coli O157. The increase in LAB and the decrease in $\mathrm{pH}$ during the first hours do not seem to be effective in controlling E. coli O157 growth. Ripening is able to inhibit its survival, however, as observed in the reduction by $3 \mathrm{log}$ from the maximum concentration during the earlier stages of production. The gradual reduction in $A_{w}$, associated with constantly high LAB concentration, could play an important role in reducing the concentration of $E$. coli O157. Its potential presence in the production of raw milk cheese should be kept in mind because the infectious dose of E. coli $\mathrm{O} 157$ is only a few cells. To the best of our knowledge, no scientific studies reporting E. coli O157 in Fontina PDO cheese have been published to date, nor have samples been found positive during official control analyses in our food laboratory over the years. This could be linked to either its low incidence in the milk used for making Fontina PDO or a low level of contamination that is eliminated during cheese ripening. It is essential that the milk used for raw milk cheese making be of the highest bacteriological quality.

\section{ACKNOWLEDGMENTS}

The present study received funding from the Italian Ministry of Health in the form of a centre grant: "Sviluppo e validazione di modelli matematici di microbiologia predittiva per la documentazione scientifica della sicurezza igienico sanitaria dei prodotti tradizionali italiani." The authors thank the European Union Reference Laboratory for kindly providing Escherichia coli, including verotoxigenic E. coli for the E. coli $\mathrm{O} 157$ strains used in this study.

\section{REFERENCES}

Arocha, M. M., M. McVey, S. D. Loder, J. H. Rupnow, and L. Bullerman. 1992. Behaviour of enterohaemorrhagic E. coli O157:H7 during the manufacture of cottage cheese. J. Food Prot. 55:379-381. https://doi.org/10.4315/0362-028X-55.5.379.

Baylis, C. 2009. Raw milk and raw milk cheeses as vehicles for infection by verocytotoxin-producing Escherichia coli. Int. J. Dairy Technol. 62:293-307.

Bellio, A., S. Astegiano, A. Traversa, D. M. Bianchi, S. Gallina, N. Vitale, F. Zuccon, and L. Decastelli. 2016. Behaviour of Listeria monocytogenes and Staphylococcus aureus in sliced, vacuumpackaged raw milk cheese stored at two different temperatures and time periods. Int. Dairy J. 57:15-19. https://doi.org/10.1016/ j.idairyj.2016.02.003.

Callon, C., C. Arliguie, and M. C. Montel. 2016. Control of Shigatoxin-producing Escherichia coli in cheese by dairy bacterial strains. Food Microbiol. 53:63-70.

Caprioli, A., S. Morabito, H. Brugère, and E. Oswald. 2005. Enterohaemorrhagic Escherichia coli: Emerging issues on virulence and modes of transmission. Vet. Res. 36:289-311. https://doi.org/10 .1051/vetres:2005002.

CLAL. 2017. Italia: Export Fontina, fontal. Accessed Jul. 5, 2017. http://www.clal.it/?section=imp_exp_istat\&cod $=04069076 \&$ mov $=\mathrm{E}$.

D'Amico, D. J., M. J. Druart, and C. W. Donnelly. 2010. Behavior of Escherichia coli O157:H7 during the manufacture and aging of Gouda and stirred-curd Cheddar cheeses manufactured from raw milk. J. Food Prot. 73:2217-2224.

EFSA and ECDC (European Food Safety Authority and European Centre for Disease Prevention and Control). 2016. The European Union summary report on trends and sources of zoonoses, zoonotic agents and food-borne outbreaks in 2015. EFSA J. 14:e04634. https://doi.org/10.2903/j.efsa.2016.4634.

Ercolini, D., V. Fusco, G. Blaiotta, F. Sarghini, and S. Coppola. 2005. Response of Escherichia coli O157:H7, Listeria monocytogenes, Salmonella typhimurium, and Staphylococcus aureus to the thermal stress occurring in model manufactures of Grana Padano cheese. J. Dairy Sci. 88:3818-3825. https://doi.org/10.3168/jds.S0022 $-0302(05) 73067-8$

European Union. 2002. Regulation (EC) No 178/2002 of the European Parliament and of the Council of 28 January 2002 laying down the general principles and requirements of food law, establishing the European Food Safety Authority and laying down procedures in matters of food safety. Off. J. 31:1-44. Accessed Jan. 20, 2018. http://eur-lex.europa.eu/LexUriServ/LexUriServ.do?uri=OJ:L: 2002:031:0001:0024:en:PDF

European Union. 2004. Regulation (EC) No 853/2004 of the European Parliament and of the Council of 29 April 2004 laying down specific hygiene rules for food of animal origin. Off. J. 139:55-205. Accessed Jan. 20, 2018. http://eur-lex.europa.eu/legal-content/EN/ TXT/PDF/?uri=CELEX:32004R0853\&from=EN.

Farrokh,, C., K. Jordan, F. Auvray, K. Glass, H. Oppegaard, S. Raynaud, D. Thevenot, R. Condron, K. De Reu, A. Govaris, K. Heggum, M. Heyndrickx, J. Hummerjohann, D. Lindsay, S. Miszczycha, S. Moussiegt, K. Verstrate, and O. Cerf. 2013. Review of Shiga toxin-producing Escherichia coli (STEC) and their significance in dairy production. Int. J. Food Microbiol. 162:190-212. https://doi.org/10.1016/j.ijfoodmicro.2012.08.008.

Food Standards Australia New Zealand. 2015. Imported food risk statement. Raw milk cheese and Shiga toxin-producing Escherichia coli. Accessed Jan. 20, 2018. http://www.foodstandards.gov.au/ consumer/importedfoods/Documents/Raw\%20milk\%20cheese\%20 and\%20STEC.pdf.

Govaris, A., D. K. Papageorgiou, and K. Papatheodorou. 2002. Behavior of Escherichia coli O157:H7 during the manufacture and ripening of feta and telemes cheeses. J. Food Prot. 65:609-615.

Honish, L., G. Predy, N. Hislop, L. Chui, K. Kowalewska, L. Trottier, C. Kreplin, and I. Zazulak. 2005. An outbreak of E. coli O157:H7 hemorrhagic colitis associated with unpasteurized Gouda cheese. Can. J. Public Health 96:182-184.

ISO. 2004. ISO 21807:2004. Microbiology of food and animal feeding stuffs-Determination of water activity. Accessed Jan. 20, 2018. https://www.iso.org/standard/34728.html.

ISO. 2017. ISO 6887-1:1999. Microbiology of food and animal feeding stuffs - Preparation of test samples, initial suspension and decimal dilutions for microbiological examination-Part 1: General rules for the preparation of the initial suspension and decimal dilutions. Accessed Jan. 20, 2018. https://www.iso.org/standard/26850 .html.

Melton-Celsa, A., K. Mohawk, L. Teel, and A. O'Brien. 2011. Pathogenesis of Shiga-toxin producing Escherichia coli. In Ricin and Shiga Toxins. Current Topics in Microbiology and Immunology, vol. 357. N. Mantis, ed. Springer, Berlin, Germany. 
MFHPB. 2014. MFHPB-03. Determination of the $\mathrm{pH}$ of Foods including Foods in Hermetically Sealed Containers. Accessed Jan. 20, 2018. https://www.canada.ca/en/health-canada/services/ food-nutrition/research-programs-analytical-methods/analytical -methods/compendium-methods / methods-microbiological -analysis-foods-compendium-analytical-methods.html.

Montet, M. P., E. Jamet, S. Ganet, M. Dizin, S. Miszczycha, L. Duniere, D. Thevenot, and C. Vernozy-Rozand. 2009. Growth and survival of acid-resistant and non-acid-resistant Shiga-toxin-producing Escherichia coli strains during the manufacture and ripening of Camembert cheese. Int. J. Microbiol. 2009:653481. https:// doi.org/10.1155/2009/653481.

Nobili, G., I. Franconieri, M. G. Basanisi, G. La Bella, R. Tozzoli, A. Caprioli, and G. La Salandra. 2016. Isolation of Shiga toxinproducing Escherichia coli in raw milk and mozzarella cheese in southern Italy. J. Dairy Sci. 99:7877-7880. https://doi.org/10 .3168/jds.2016-11613.

Ramsaran, H., J. Chen, B. Brunke, A. Hill, and M. V. Griffiths. 1998. Survival of bioluminescent Listeria monocytogenes and E. coli O157:H7 in soft cheese. J. Dairy Sci. 81:1810-1817.

RASFF. 2017. RASFF for safer food-The Rapid Alert System for Food and Feed-2016 Annual Report. Accessed Jan. 20, 2018. https://ec.europa.eu/food/sites/food/files/safety/docs/rasff _annual_report_2016.pdf.

Ravel, A., J. Greig, C. Tinga, E. Todd, G. Campbell, M. Cassidy, B. Marshall, and F. Pollari. 2009. Exploring historical Canadian foodborne outbreak data sets for human illness attribution. J. Food Prot. 72:1963-1976.

Regione Piemonte. 2017. Piano Regionale Integrato dei Controlli di Sicurezza Alimentare. Accessed Jan. 20, 2018. http://www.regione .piemonte.it/sanita/cms2/alimenti/controlli-ufficiali/1259-piano -regionale-integrato-dei-controlli-di-sicurezza-alimentare-prisa.
Reitsma, C., and D. Henning. 1996. Survival of enterohemmorrhagic Escherichia coli O157:H7 during the manufacture and curing of cheddar cheese. J. Food Prot. 59:460-464.

Italiana, R. 2011. Disciplinare di produzione della DOP FONTINA. Gazzetta Ufficiale. 52:21-30.

Ryser, E. T. 2011. Pasteurization of liquid milk products: Principles, public health aspects. In Encyclopedia of Dairy Sciences. J. W. Fuquay ed. Academic Press, San Diego, CA.

Schlesser, J. E., R. Gerdes, S. Ravishankar, K. Madsen, J. Mowbray, and A. Y. L. Teo. 2006. Survival of a five-strain cocktail of Escherichia coli O157:H7 during the 60-day aging period of Cheddar cheese made from unpasteurized milk. J. Food Prot. 69:990-998.

Spano, G., E. Goffredo, L. Beneduce, D. Tarantino, A. Dupuy, and S. Massa. 2003. Fate of Escherichia coli O157:H7 during the manufacture of mozzarella cheese. Lett. Appl. Microbiol. 36:73-76.

Trevisani, M., R. Mancusi, G. Delle Donne, C. Bacci, L. Bassi, and S. Bonardi. 2014. Detection of Shiga toxin (Stx)-producing Escherichia coli (STEC) in bovine dairy herds in Northern Italy. Int. J. Food Microbiol. 184:45-49. https://doi.org/10.1016/j.ijfoodmicro .2013.12.033.

Vernozy-Rozand, C., C. Mazuy-Cruchaudet, C. Bavai, M. P. Montet, V. Bonin, A. Dernburg, and Y. Richard. 2005. Growth and survival of Escherichia coli O157:H7 during the manufacture and ripening of raw goat milk lactic cheese. Int. J. Food Microbiol. 105:83-88.

Wahi, S., S. Bansal, M. Ghosh, and A. Ganguli. 2006. Growth and survival of Escherichia coli O157:H7 during manufacture and storage of Indian cheese (paneer). Foodborne Pathog. Dis. 3:184-189. https://doi.org/10.1089/fpd.2006.3.184 